\title{
Correlative Evaluation of the Impact of Adaptive Plant Morphology on Bioactive Accumulation Based on Micro-Morphological Studies in Andrographis serpyllifolia (Rottler ex Vahl) Wight
}

\author{
Suma KRISHNASWAMY'1*, Bopaiah A KUSHALAPPA ${ }^{2}$ \\ ${ }^{1}$ Research and Development Centre, Bharathiar University, Department of Botany, Coimbatore-641046, Tamil Nadu, \\ India; sumakrishnaswamy@gmail.com (*corresponding author) \\ ${ }^{2}$ St. Joseph's College for Post Graduate Studies, Department of Botany Langford Road, Bangalore-560 027, India; bopaiah59@yahoo.co.in
}

\begin{abstract}
Does the adaptive plant morphology actually hint at its potential bioactive profile? To understand and decipher this, a micro-morphological investigation was conducted on an arid zone plant. Andrographis serpyllifolia (Rohl.ex.vahl.) Wight is a slightly bitter, acrid endemic herb with fair history of ethno-botanical use among different tribes of peninsular India. $A$. serpyllifolia was a highly evolved geophyte well-suited for high survivability in extremely harsh terrain. This plant was found to grow and perpetuate successfully under high-stress conditions of water deficit, high soil and atmospheric temperatures, poor nutrition and constant threat from herbivores. Under such circumstances, this plant possessed the potential to develop morphological adaptations that produce and accumulate a wide range of phytochemicals that could preserve, protect and defend its plant body. The twin objectives of this study were to investigate the micro-morphological features and their functional advantage that enabled this plant to flourish in adverse conditions and interpret by deductive reasoning, the potential phytochemical array of this plant given the observed features. Scanning electron microscope was used to explore surface morphologies of various vegetative and floral parts. Key findings of this micro-morphological study were presence of numerous diacytic stomata on both adaxial and abaxial leaf surfaces, abundant glandular sessile trichomes on abaxial leaf surfaces, reticulate pollen ornamentation with echinate sulcus outlined with smooth morus and deeply reticulate, highly pitted spermoderm or seed testa reminiscent of human brain. These three features may serve as pharmacognostic markers aiding in accurate identification and quality control of this herb.
\end{abstract}

Keywords: diacytic stomata, pollen ornamentation, SEM, testa, trichome morphology.

\section{Introduction}

Andrographis serpyllifolia (Syn. Andrographis orbiculata, Eriathera serpyllifolia) belonging to the family Acanthaceae has a unique, distinctive morphology not observed in any other species of Genus Andrographis. This genus is represented by 42 species (Missouri Botanical Gardens, Parixit et al., 2012) all of which are upright erect much branched herbs except for $A$. rothii (eflora of India, 2015), which is a prostrate herb. Andrographis serpyllifolia is found in the Deccan thorn scrub forest, an arid ecoregion receiving annual rainfall less than 750 millimetres during the brief wet season and practically no rainfall from November to April (Champion and Seth, 1968). The ambient temperature exceeds $42{ }^{\circ} \mathrm{C}$ during peak summer. Defined as the 'peninsular hot arid zone', this harsh ecoregion sprawls across the Southern Indian states, Tamil Nadu, Andhra Pradesh and Karnataka (Rao et al., 2014). A. serpyllifolia has been described as densely hispid herb, with orbicular leaves, single flowers in short racemes in upper axils, calyx lobes glandular- hairy without, corolla white with pink tinge, glandular hairy, anthers unequal oblong, both cells bearded, ovary puberulous, style hairy, fruit a capsule acute below, shortly acuminate above, seeds with spoon shaped retinacula, rootstock stout with branch-lets spreading up to $50 \mathrm{~cm}$. Flowering is between June to September and January to March (Mathew, 1990). Different authors describing this plant are in agreement with this description (Saldanha and Nicolson, 1976; Keshavamurthy and Yoganarasimhan, 1990; Manjunath et al., 2003). Rootstock was described as underground part of a plant, from which new above-ground growth can be produced and can refer to a rhizome or underground stem (Hickey and King, 2001). Geophyte was defined as a "perennial plant with an underground food storage organ and 
264

aerial parts that die away during adverse conditions as in winter or during dry season, regenerating at the onset of favourable conditions" (Houghton, 2005). This description is apt in the case of A. serpyllifolia whose subterranean stout rootstock progressively reduces its leaf size with increasing summer temperatures, sheds the aerial parts that get completely scorched and the apices become dormant stubs just under the soil surface. With lowering temperatures and onset of monsoon, the subterranean rootstock sprouts a number of radially arranged shoots each of which is bilaterally symmetrical.

A detailed study of the surface morphology was undertaken using Scanning Electron Microscope to understand the basic micro morphological structure of the plant and to unravel the probable functions assigned to each organelle. Scanning electron microscopy is an ideal technique for high resolution investigations of plant tissue surfaces and has the potential to provide excellent low magnification images of plant surfaces in their nativehydrated state (Pathan et al., 2009). In addition, it allows the flexibility to alter stage temperature and vapour pressure in the specimen chamber. Plant tissues can be examined at high humidity in the chamber and minimize sample dehydration during the imaging process. Since the live tissues can be studied with low electron dose of $2-3 \mathrm{Kv}$, the hydrated to dehydrated samples retain their native tissue integrity and artefacts can be reduced considerably. Texture of trichome surfaces, pollen ornamentation and seed testa are observed in great detail. A drawback of SEM technology is that surface waxes and cuticle are not clearly visible and samples collapse at higher magnifications $(5000 \mathrm{x})$.

This study highlighted the presence of diacytic stomata and distribution of glandular sessile trichomes on lower surface of the leaves, spheroidal tricolporate pollen and seed testa. These features serve as markers for accurate identification and quality control of this herb.

The purpose of this morphological study was to understand the organelle structure and their functional role that contributes to the phytochemical signatures of this plant. The presence or absence of associated organelle structure facilitates focussed bioactive screening, rendering exhaustive and expensive phytochemical screening redundant.

\section{Materials and Methods}

\section{Site selection and plant material authentication}

The whole plant was collected from wild populations in different thorny scrub jungles locations in Bangalore $\left(12^{\circ}\right.$ $\left.58^{\prime} 20.7912^{\prime \prime} \mathrm{N}, 77^{\circ} 34^{\circ} 50.3148^{\prime \prime} \mathrm{E}\right)$, Doddaballapur $\left(13^{\circ} 18^{\prime} 0.62^{\prime \prime} \mathrm{N} 77^{\circ} 32^{\prime} 19.45^{\prime \prime} \mathrm{E}\right)$, Chamarajanagar $\left(11^{\circ} 55^{\prime}\right.$ $34.1292^{\prime \prime} \mathrm{N} 76^{\circ} 56^{\prime} 37.4388^{\prime \prime}$ E) and Malavalli $\left(12^{\circ} 22^{\prime} 48^{\prime \prime} \mathrm{N}, 77^{\circ} 4^{\prime} 48^{\prime \prime} \mathrm{E}\right)$ districts in the state of Karnataka, India between July and August 2015 and authenticated by researchers at Plant Survey Division, National Ayurveda Dietetics Research Institute, Bangalore (Central Council for Research in Ayurvedic Sciences (CCRAS), Department of AYUSH, Ministry of Health and Family Welfare Government of India, New Delhi). A voucher specimen was deposited in the herbarium for future reference (Reference No. RRCBI-5019).

\section{Plantmaterial}

A. serpyllifolia (Fig. 1 A) can be described as a Geophyte with a stout rootstock with numerous apical meristems that sprout into flat bilaterally symmetrical branches arranged in radial symmetry at the top of the rootstock. The aerial parts are all covered by numerous very fine, stiff hairs or trichomes. The orbicular sub-sessile leaves (Fig. 1 B) are small sized, opposite, decussate, exstipulate, without spines, thick, hardy, succulent, smooth, entire, ovoid in shape and glossy with blunt or obtuse apex. Young juvenile stem is unbranched, purplish wiry, round with numerous white to translucent glandular and simple trichomes all along its length. The older stem is brown to greenish in colour, woody, branched, flexible and also bears numerous trichomes. Flowers (Fig. 1 C) are axillary and stand erect as a solitary cyme, placed perpendicularly to the axis of the leaf in close proximity of each other, flowers are attractive, white, zygomorphic, monoecious, hermaphrodite with characteristic violet- purple markings that make a consistent design on the delicate corolla. The calyx has five pubescent sepals that are fused at the base. Corolla is sympetalous, resupinate by $180^{\circ}$ - twisting of corolla tube, bilabiate, tubular, funnel form. Corolla tube is deeply split adaxially with the upper lip of the corolla cut away almost to the base of the tube. The three lower petals are fused at the base with distinctive deep maroon to deep chocolate brown markings The central broad lower petal bears an inverted pointed cup-like marking and is flanked by two narrow petals both of which bear marking of an inverted trident. These markings on the petals of corolla are consistent and typical of $A$. serpyllifolia from various geographic regions. The upper lip which bears numerous white fine hairs is formed by fusion of two petals. It is very broad along the outer edge of the flower and tapers inward towards the yellowish throat. The bearded anther is deep maroon and is borne on a bifid filament which is fused at both ends and free all along its length (Fig. $1 \mathrm{D})$. The anther thecae usually open by longitudinal slits (Fig.1 E). The pollen (Fig. $1 \mathrm{G}$ ) exhibits a reticulate pattern, a character useful in generic distinction. The yellow seed is ovoid, laterally compressed, with deep ridges and furrows $($ Fig. $1 \mathrm{H})$.

\section{Method ofstudy}

The equipment used for this study was FEI Quanta FEG 250 system which is designed to study and image hydrated samples. The QuantaSEM system is equipped with analytical systems, such as energy dispersive spectrometer, wavelength dispersive $\mathrm{x}$-ray spectroscopy and electron backscatter diffraction. In addition, the field emission gun (FEG) systems contain an S/TEM detector for bright-field and dark-field sample imaging with variable size of the motorized stage $(50 \mathrm{~mm}, 100 \mathrm{~mm}$ and $150 \mathrm{~mm}$ ) and with an integrated digital image acquisition system. Fitted with a conventional tungsten electron source giving a resolution of $3.5 \mathrm{~nm}$ it is equipped with a range of detectors including Secondary Electron (SE), Back Scattered (BSE), Energy Dispersive X-ray analysis (EDS), an internal TV camera (CCD) and a range of special detectors for using the SEM in LV or ESEM mode. (FEI Company, 2012). 

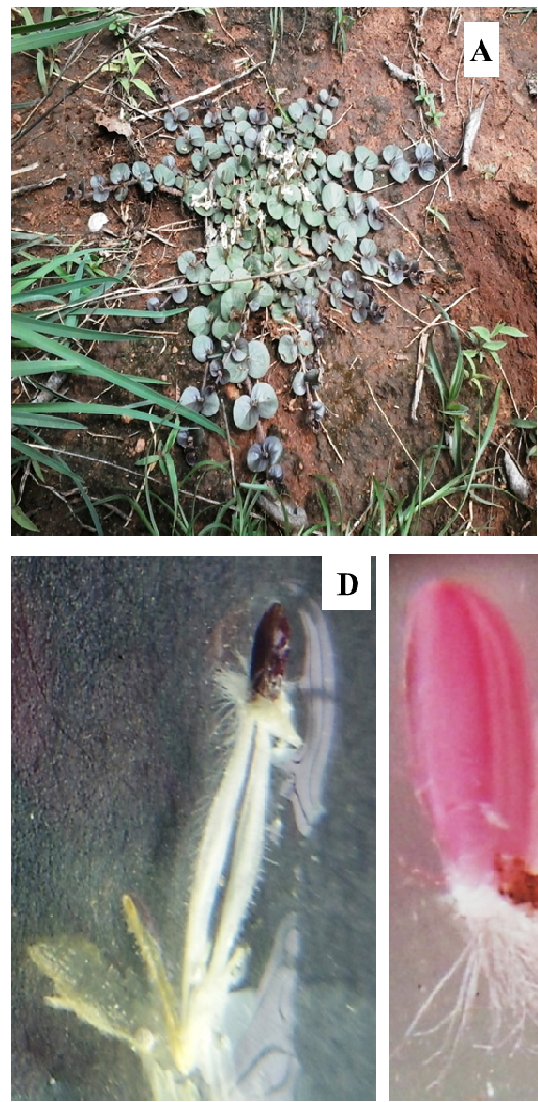
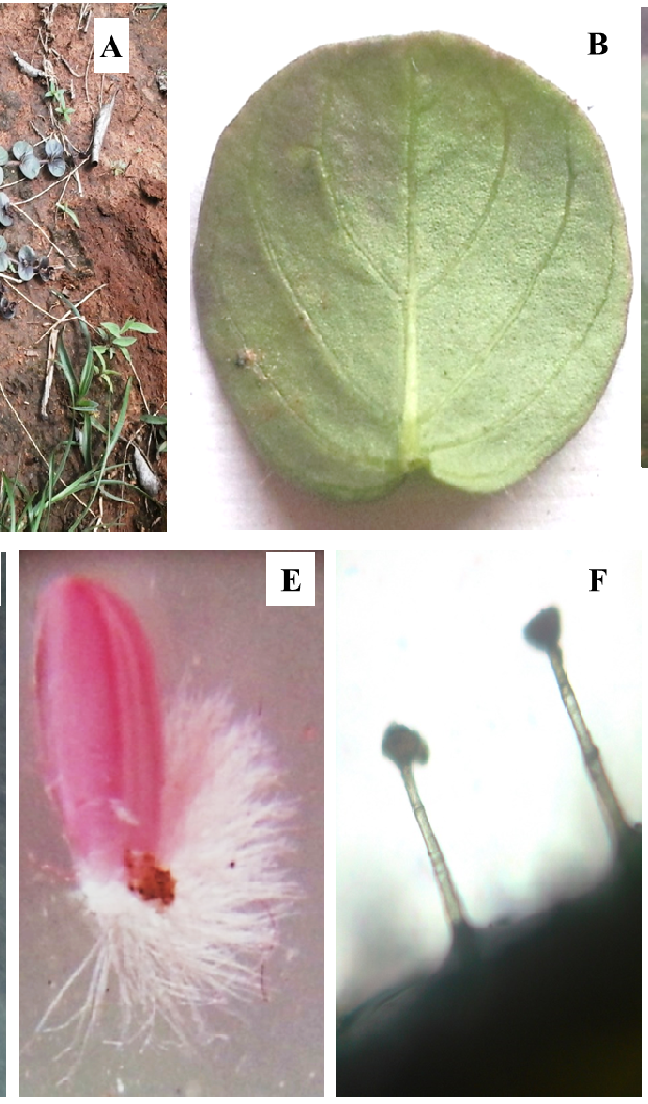

F
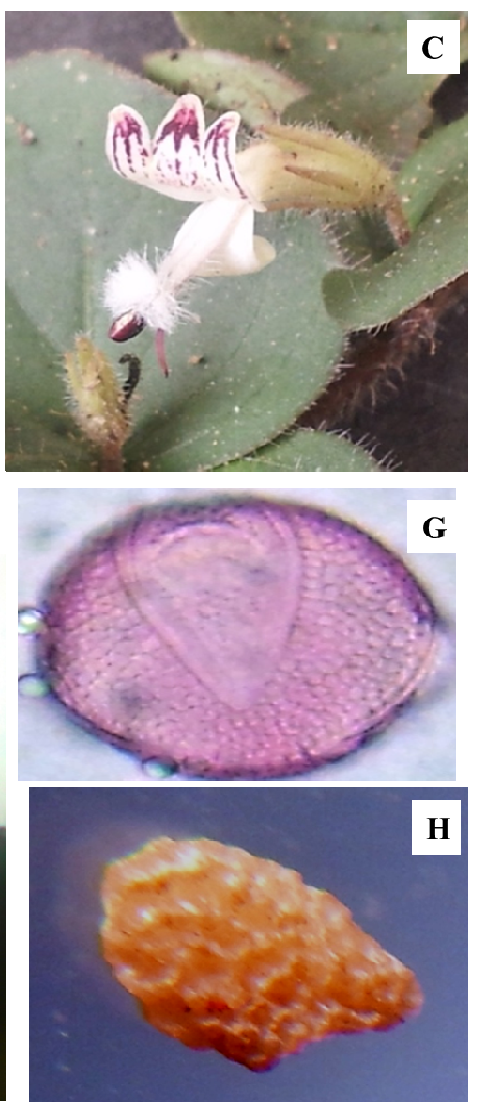

Fig. 1. A. Plant in its natural habitat; B. Orbicular sessile leaf; C. Flower bearing characteristic markings and anther with numerous hairs; D. Close up of androecium: bifid style with trichomes and anther; E. Close up of anther revealing longitudinal slits, numerous white basal hairs; F. Close up of multicellular glandular trichomes; G. Pollen grain with reticulate exine; H. Seed with "brainy" testa

\section{Samplepreparation}

The freshly collected plant samples were prepared by washing with a fine jet of water to prise out the mud and extraneous particles stuck among the numerous hairs on the plant surfaces. Excess moisture was dabbed out with soft tissue paper taking care not to crush the plant material. The tissues were then stabilized using Methanol as fixative for 30 seconds (Neinhuis and Edelmann, 1996) followed by dehydration in ethanol and air drying. Dried material was mounted directly on stubs using double-side adhesive tape, and sputtered with a thin layer of platinum to enhance electrical conductivity of the tissues, using a "Sputter Coater" (Schweitzer, 2014). The electron micrographs were obtained in a high vacuum mode at a spot distance of 2.5 $\mathrm{mm}$ at $2.5 \mathrm{kV}$.

\section{Plantparts used as specimens formorphological studies}

Detailed study of the vegetative morphology of the plant, using leaf, stem, epidermal surface, stomata, trichome types and distribution was undertaken. The floral morphological studies included, unopened flower bud collected just ahead of anthesis, pollen and seeds.

\section{Result}

\section{Leafmorphology}

The tender apical shoot with first two pairs of leaves (Fig. $2 \mathrm{~A}$ ) mounted on the metal holder was observed to have numerous trichomes on the stems, leaves, nodes and internodes. The long multi-cellular simple trichomes arising from rounded basal cells are broad at the base and taper to a pointed end. These are sparsely distributed on the laminar surfaces and are more concentrated towards the dorsal, ventral margins and tips of the leaf.

An expanded view of the leaf surface clearly highlights numerous diacytic stomata (Fig. 2 B) both on the dorsal and ventral surfaces. The stomata are distributed evenly across the leaf surface and can be oriented in any direction. The bean-shaped guard cells flank the stoma or osteole. The axis of the two subsidiary cells lies perpendicular to the axis of the stoma. Each stoma is surrounded by two to three irregularly shaped, axially elongated epidermal cells or subsidiary cells (Fig. 2 C). The epidermal cells bear striations (Fig. $2 \mathrm{D})$ that run parallel to the cross axis and perpendicular to the long axis of the cells. The orbicular leaves bear along their dorsal, ventral margins and around the tips, many multicellular, uniseriate, simple trichomes (Fig. $3 \mathrm{~A}$ ) that have an elongated pointed tapering end. The ventral surface bears numerous pin-headed, glandular, sessile trichomes (Fig. 3 B, C, D) that are randomly distributed between the veins. The midrib comprises of linearly arranged barrel shaped cells of uniform size and shape, interspersed with trichomes (Fig. $3 \mathrm{~B}$ ). While the main veins lacked any trichomes, secondary veins bear a few sparsely distributed glandular sessile trichomes. 

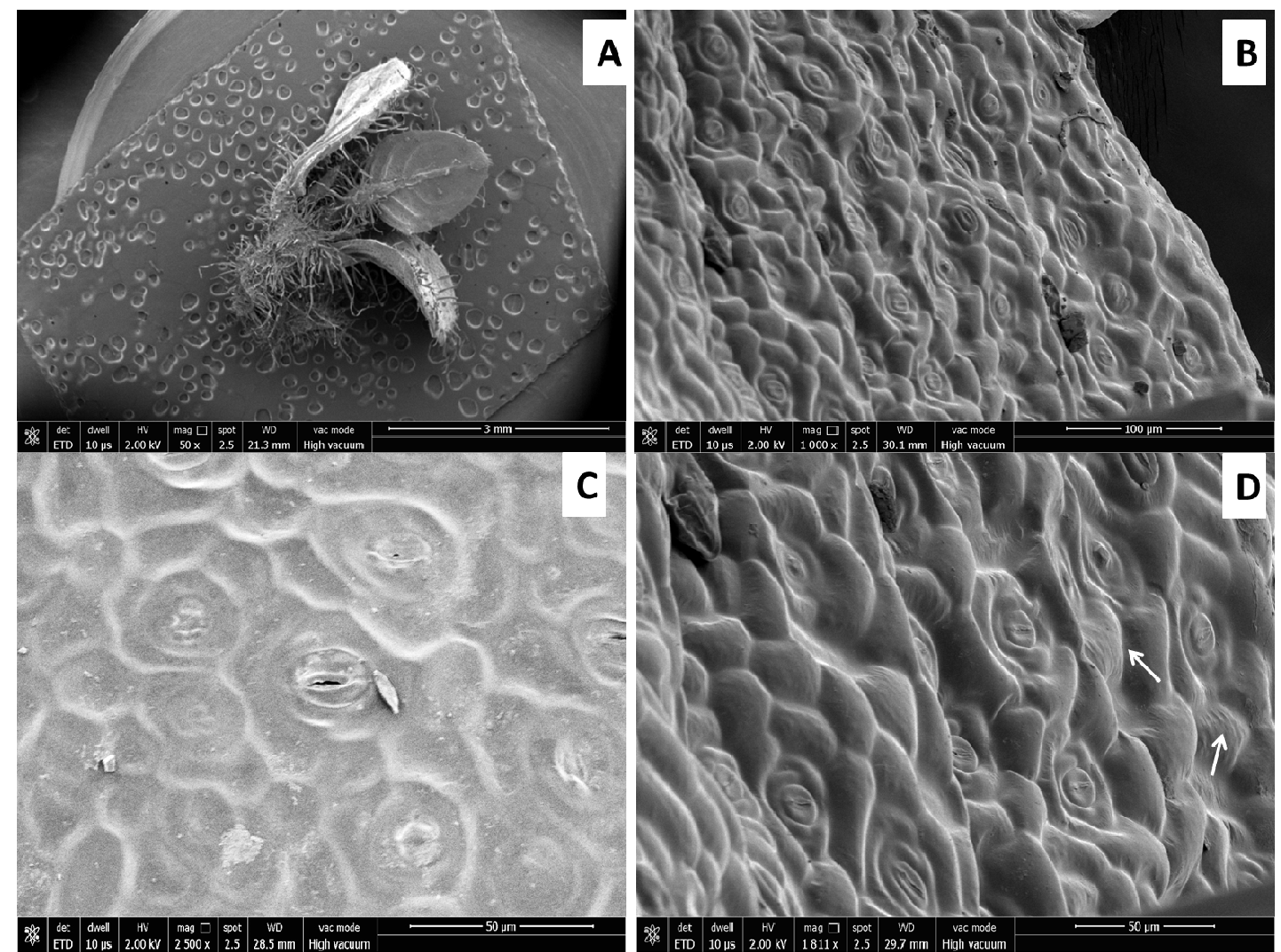

Fig. 2. A. Plant habit with numerous trichomes on stem and leaves; B. Distribution of stomata on leaf; C. Diacytic stomata surrounded by four irregularly shaped epidermal cells; D. Striations on epidermal cells
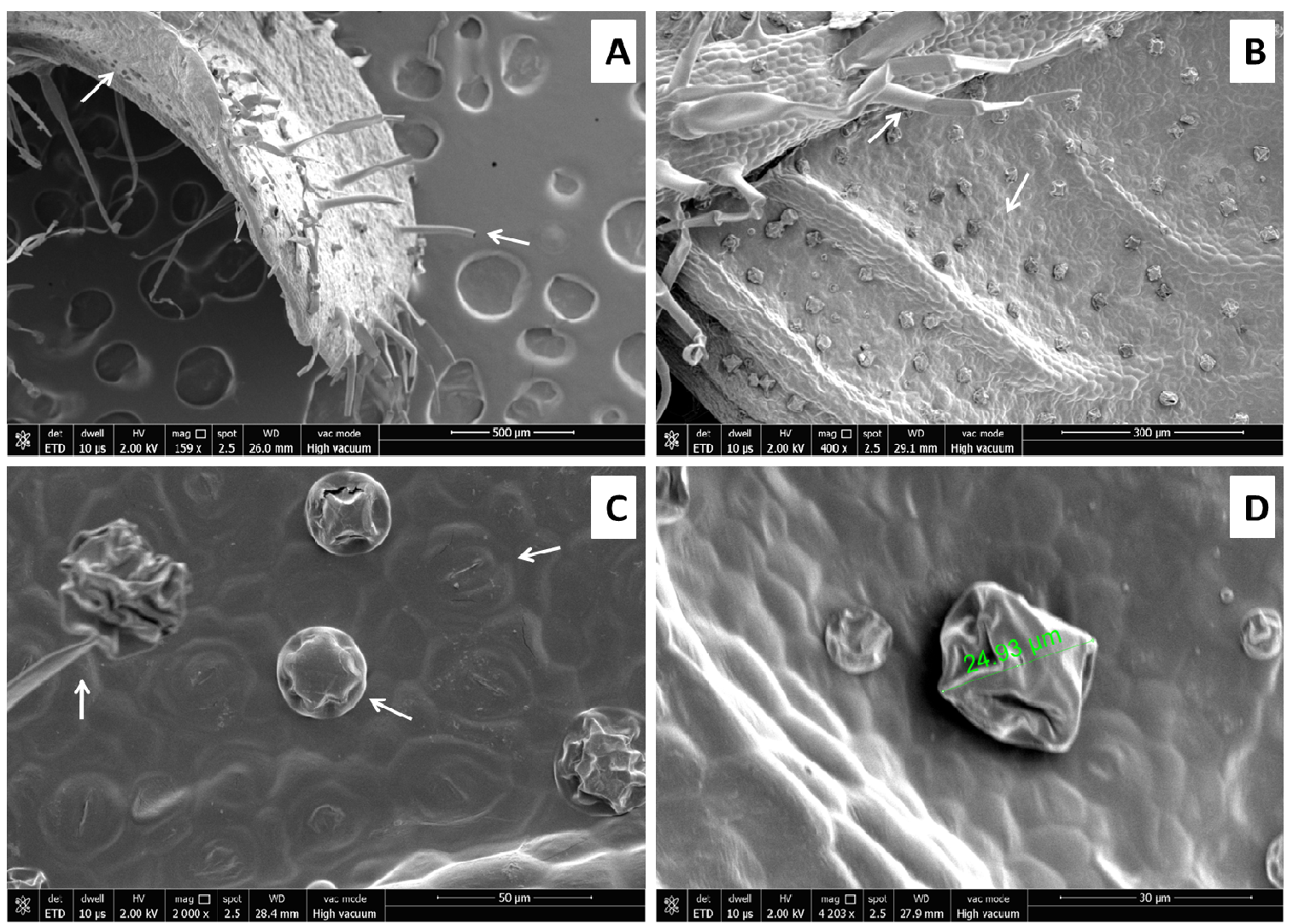

Fig. 3. A. Simple trichomes at leaf margins on adaxial surface and numerous sessile trichomes on abaxial surface; B. Ventral surface of leaf highlighting sessile glandular trichomes between secondary veins and multicellular simple trichomes on midrib; C. Stalked glandular trichome, sessile glandular trichome and many stomata with closed stoma on ventral surface of leaf; D. Closeup of sessile glandular trichome 

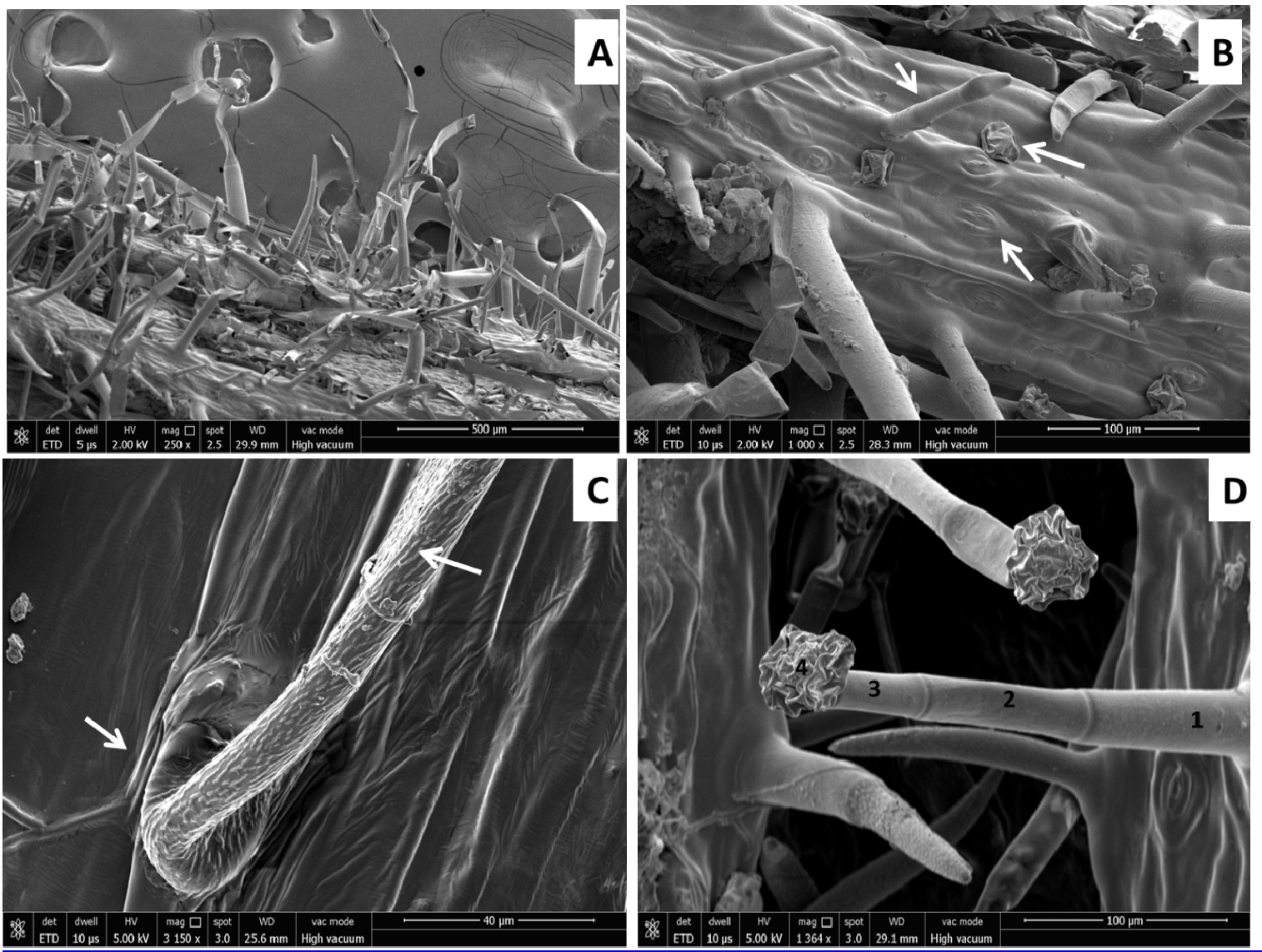

Fig. 4. A. Portion of stem covered with numerous simple trichomes; B. Ultrastructure of Stem with simple trichomes, sessile trichomes and closed stomata; C. Mottled or streaked surface of multicellular trichome emerging from rounded basal cell; D. Multicellular glandular trichome and simple trichomes interspersed on stem surface

\section{Stem morphology}

The stems (Fig. 4 A) are profusely covered with multicellular uniseriate simple trichome; glandular pin headed trichomes mounted on multicellular stalks and sessile glandular trichome (Fig. 4 B) that comprises of a rounded multi cellular pin head without stalk. There are a few stomata (Fig. 4 B) distributed among the trichomes on the stems. Each trichome emerging from a rounded basal epidermal cell consists of two to three cells bearing numerous short white disconnected streaks on the surface that gives a speckled appearance (Fig. $4 \mathrm{C}$ ). The round glands are borne on three celled stalks in stalked glandular trichomes and have a translucent appearance (Fig. 4D).

\section{Floralmorphology}

The flowers and flower buds (Fig. $5 \mathrm{~A}$ ) bear abundant multicellular uniseriate simple trichome (Fig. 5 B). Stalked or sessile glandular trichomes were not observed in the flower specimen examined. The floral trichomes appear spotted with white dot-like deposits that are arranged in a fairly uniform pattern (Fig. $5 \mathrm{C}$ ). As they grow longer in length, the simple tapering trichomes seem to get skewed (Fig. 5 D).

\section{Pollen morphology}

The androecium comprises of two epipetalous stamens mounted on two separate filaments (Fig. $6 \mathrm{~A}$ ) that are fused at the proximal and distal ends but free all along its length. The stamen consists of didymous, bilocular and basifixed deeply colored anther. There are numerous fine white hairs at the junction of anther and filament earning it the name "bearded anther". Pollen production is abundant (Fig. 6 B, C). The pollen grain is spheroidal, tricolporate, with three equatorially located spherical pores and colpi (Fig. 6 D, E). The exine is reticulate with raised polygonal outlines with depressed spherical, smooth, inner surface within the polygons (Fig. $6 \mathrm{D}$ ). The three boat shaped colpi are equidistantly placed and each bears a centrally located pore. The porus is covered with a thick textured membranous, highly undulated film which may be the annulus or the callose plug protecting the inner contents of the pollen grain till it gets hydrated sufficiently enough to trigger off the pollen tube emergence. The colpus is smooth with thinner sexine along the margocolpus or outer margins. The interlying area between the porus and the outline of the margocolpus is filled with raised echinate protuberances (Fig. 6 E).

\section{Seed morphology}

The seed is ovoid at distal end and slightly flattened at the proximal hilar end (Fig. $7 \mathrm{~A}$ ) being markedly protruded on one side. The micro sculpture of testa or the outer seed coat is osseous, irregularly grooved, glabrous, and rugosepitted and resembles convolutions observed in the human 

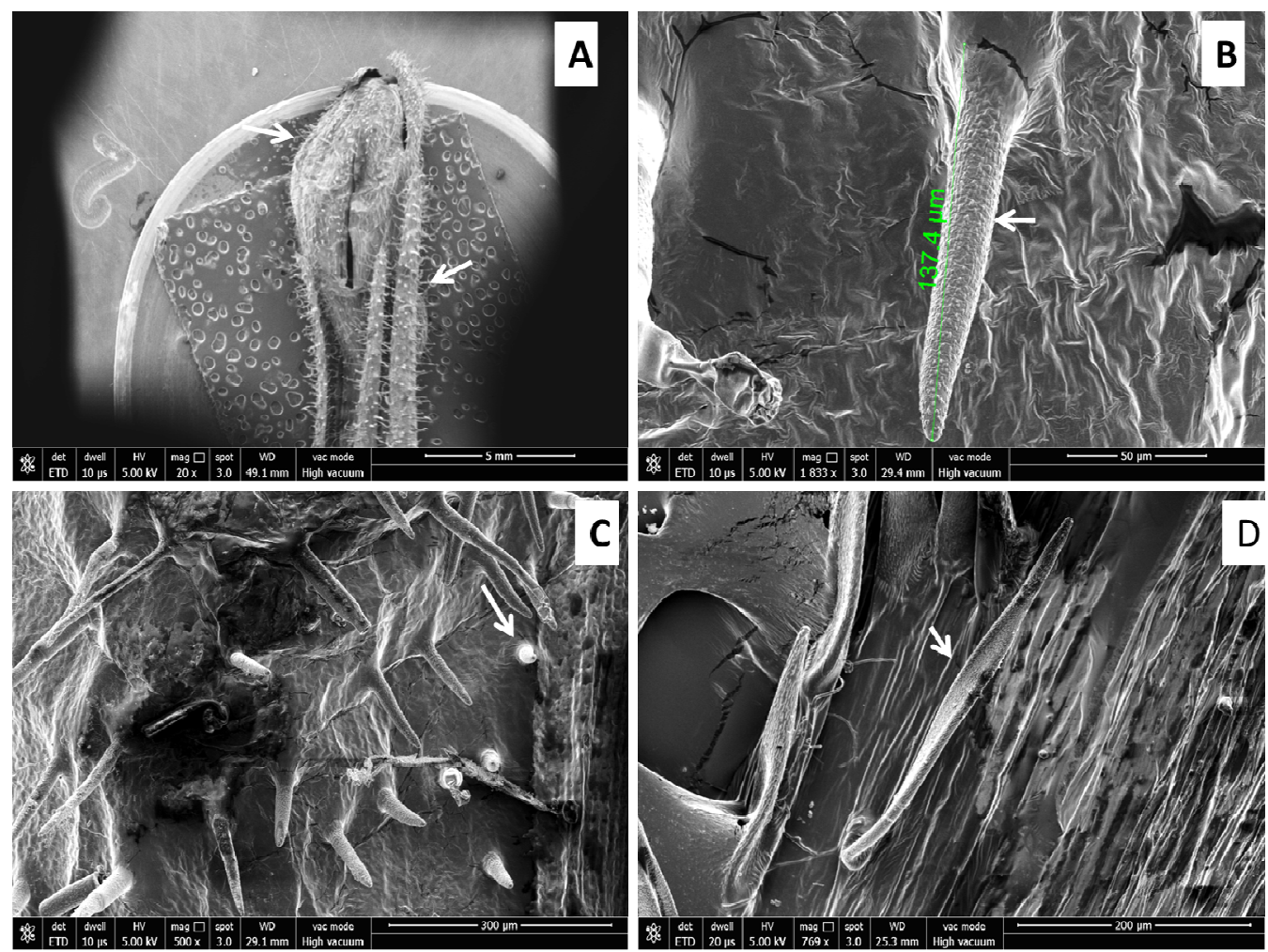

Fig. 5. A. Calyx and corolla of an unopened flower bud densely covered with simple trichomes; B. Spotted appearance of simple floral trichome; C. Simple trichomes in varying stages of development on petal; D. Older longer trichomes on lower part of calyx assume a skewed appearance
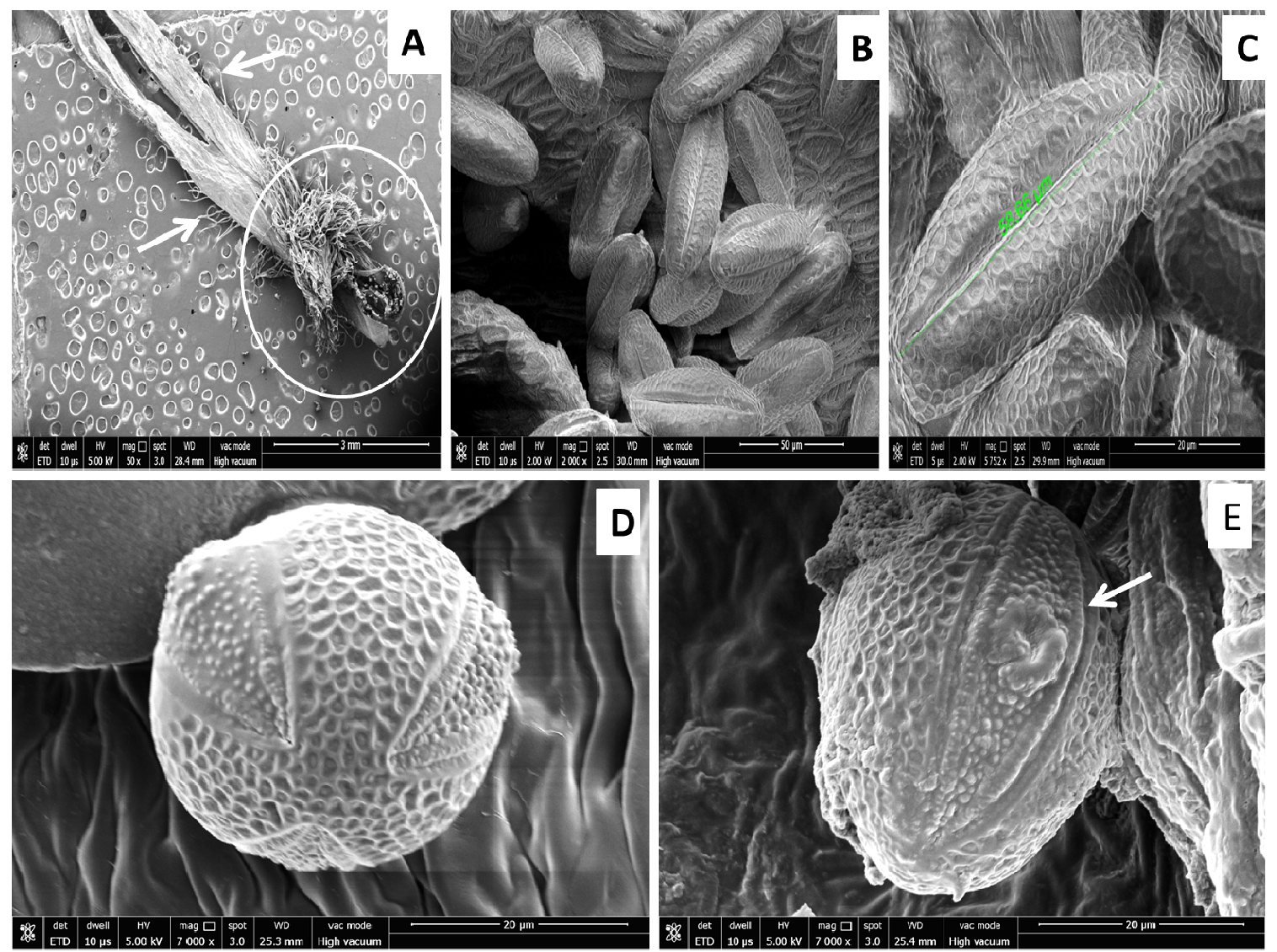

Fig. 6. A. Bifid filament bearing numerous hairs at the base of anther (damaged to reveal young developing pollen); B., C. Close up of the developing pollen; D. Polar view of mature pollen highlighting ornamentation and sulcus; E. Pore in sulcus region 

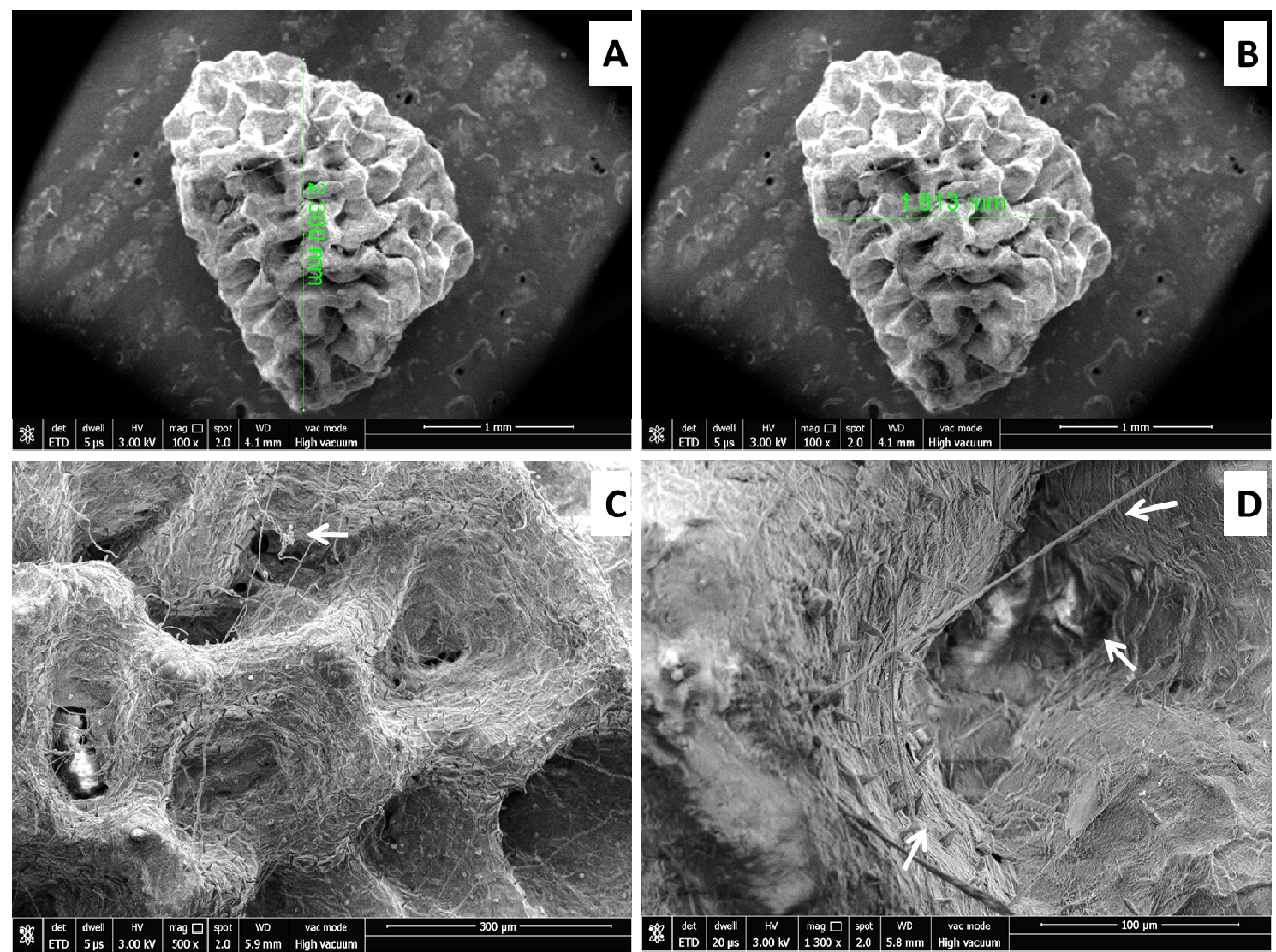

Fig. 7. A. Measurement of the seed along main axis; B. Measurement of seed along cross axis; C. Ultrastructure of testa highlighting polygonal ridges covered by numerous fine fibrillar structures and encompassing a depression; D. Ultrastructure of the polygonal ridge reveal small spines on the inner wall, criss-cross fibrils and a centrally located pore like structure
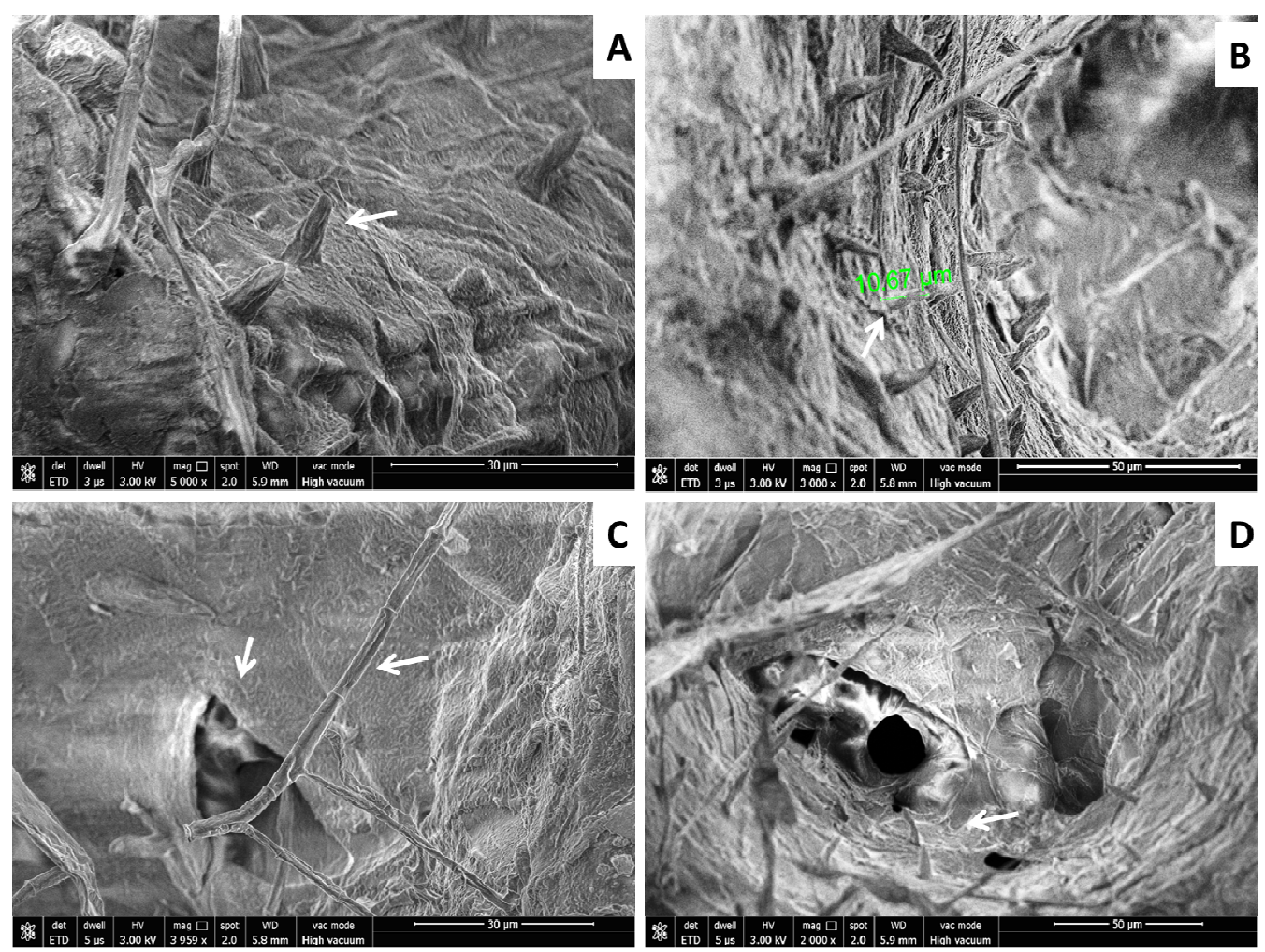

Fig. 8. A. Ultrastructure of seed testa: minute spines scattered on the inner wall of polygonal ridge; B. Measurement of the spines; C. Overhanging branched segmented fibrillar structures above the pore; $\mathrm{D}$. Thin membranous structure around a circular pore located in the depression of the polygonal ridge 
270

brain causing it to be described as "Brainy Testa" (Fig. 7 B). There are numerous contusions and depressions dividing the surface into polygonal segments of irregular sizes and shapes (Fig. 7 C) .Ultrastructure of the testa reveals several triangular to hexagonal raised ridges tapering down to a valley like depression where membranous testa thins out to form a pore. (Fig. $7 \mathrm{D}$ ). The ridges and the furrows are all covered by very fine strands giving it a fuzzy appearance. The inner walls of the ridges bear numerous short stout pointed spines (Fig. $8 \mathrm{~A}$ ) distributed randomly around which the fine strands or fibrils are seen criss- crossing (Fig 8 B). These spines (Fig. $8 \mathrm{~B}$ ) measure an average length of 10.6 $\mu \mathrm{m}$. These fibrils (Fig. $8 \mathrm{C}$ ) are segmented, branched and appear to anchor to the spines on the inner walls. The wall of the pore is thin, membranous and its edges are slightly upwardly and outwardly protruding (Fig. $8 \mathrm{D}$ ).

\section{Discussion}

\section{Habit}

Exhibiting a wide range of adaptability to adverse environmental conditions, the geophytic habit acquired by A. serpyllifolia clearly points to a drought escaper - type of life form (Raunkier, 1937). The term Geophyte, describes plant forms resting in dry ground to escape adverse conditions and which await return of favourable conditions. The group may be further subdivided into rhizome, stemtuber, root-tuber, bulb and root geophytes. Such plants are known to store carbohydrates and starches that form the source of energy for the apical buds when they are ready to emerge from dormancy. Further, given that the soil and atmospheric temperatures could rise to $42{ }^{\circ} \mathrm{C}-45^{\circ} \mathrm{C}$ the subterranean roots could also accumulate certain functional bioactives that may retard water loss or help resist excess heat. Terpenoids are highly volatile substances made of isoprene units. Isoprene, a gas produced in the chloroplasts and released by the leaves is thought to protect the plant from heat. There was excess accumulation of flavonoids, tannins, phytosterols and glycosides in the roots of Urginea indica an ethno-medically significant geophytic corm (Pandey, 2014). Flavonoid production is triggered as a stress-response and dihydroxy B-ring-substituted flavonoids have great potential to inhibit the generation of reactive oxygen species (ROS) and reduce the levels of ROS once they are formed, i.e., to perform antioxidant functions. 'Antioxidant' flavonoids are found in the chloroplast, which suggests a role as scavengers of singlet oxygen and stabilizers of the chloroplast outer membranes (Agati et al., 2012). Young juvenile stem and leaves are deep purple in colour possibly indicating an anti-predator strategy with accumulation of anthocyanins/alkaloids. Another Acanthaceae member with a ground-hugging geophytic habit similar to A.serpyllifolia, Lepidagathis incurve also bears pink to deep purple stem and internodes. The upright herb, $A$. paniculata, bears uniformly green stem with no coloration and is considered a distinguishing feature of this species. The flowers bear characteristic maroon to chocolate brown markings on the corolla in a consistent design with very little variation. These markings typical of $A$. serpyllifolia appear to be genetic trait and not a function of environment. In $A$. paniculata, there is a great degree of variability in these markings. White flowers that show up well in the dark may imply nocturnal entemophilous pollination strategy which in turn may hint at presence of terpenes or sweet smelling volatiles that attract these insects.

\section{Stomata}

The mono-layered epidermis is covered with a waxy cuticle and bears typical epidermal structures like stomata and various types of trichomes. The diacytic, diallelocytic (associated with two subsidiary cells) stomata found in $A$. serpyllifolia is typical of the genus Andrographis. Metcalfe and Chalk (1950) described this type of stomata as "usually of the so-called caryophyllaceous type being accompanied by two subsidiary cells whose common wall is placed transversally to the pore". However, both paracytic and anomocytic stomata in $A$. marcrobotrys, anisocytic stomata in $A$. stellulata and polocytic stomata in $A$. elongate were reported by Thakur and Patil (2014). While the distribution of stomata is restricted to abaxial or lower surface in the upright herb, A. paniculata (Dharmadasa et al., 2013), numerous stomata are found dispersed on both abaxial and adaxial surfaces of the leaves as well as the stems in $A$. serpyllifolia. The small stoma or areole is flanked on either side by two small beans shaped elliptical, chlorophyllous guard cells and surrounded by two to three epidermal cells with irregular margins. The epidermal cells influence the opening or closure of guard cells as their movement is a direct function of the tugor pressure. Higher water deficit in the epidermal cells render them flaccid and the guard cells also collapse and shut. Guard cells derive water from the adjoining epidermal cells and hence water content of the latter is bound to affect this phenomenon.

But the high number of stomata also means high transpiration rates (Grant, 2004). In this context, the flat two dimensional architecture of $A$. serpyllifolia with its proximity to soil surface in arid region, becomes a significant adaptation. High ambient temperatures tend to keep stomata open. It could be a strategy for rapid cooling by losing moisture to create a humid microclimate around the plant body in particularly hot conditions. This real-time pulse discharge of moisture may help to save the cells and its various organelles from getting scorched by sun's heat from above and the heat emanating from the hot earth below.

\section{Trichomes}

The foliar and floral trichomes in A. serpyllifolia are of three types: a) Multicellular simple trichomes with a pointed tapering tip; b) Multicellular stalked trichomes ending in around glandular pin head; c) Sessile round glandular pinhead. The distribution of these trichomes as listed in Table 1 is extremely dense in some plant parts suggesting alternative functions aside from the commonly assumed protective role, guarding the plant body from radiation, sun and heat. The numerous multicellular simple trichomes which are found on the leaves, stem and other aerial parts, are also called "covering trichomes" may serve as filters for dust particles that could physically clog the stoma or areole of the stomata hampering the gas and moisture exchange. Ultrastructure of the surface of these trichomes reveals short streak-like white deposits (Fig. 3 C) which did not degenerate even when subjected to the high vacuum and temperature of the SEM Chamber. These deposits may be 
some type of heat tolerant hydrophobic substances that may retard the evapotranspirational water loss in nature. These deposits are also observed in the floral trichomes though they assume a different spotted pattern (Fig. 4 B). Working on about 43 species of Loasaceae, Weigend and Ackermann (2015) demonstrated presence of biomineralization on trichome surfaces. Biominerals such as calcium phosphate and silica were found accumulating in varied patterns on different trichomes. It may worthwhile to investigate whether the white deposits on the trichomes of $A$. serpyllifolia are biominerals assuming specific orientations/patterns based on the physiological function of the trichome-bearing organelle. The pin-headed glandular trichomes on the multicellular stalk appear crumpled in the images and this could be due to excess dehydration that caused shrinkage while processing the plant material for study or due to the prevalent conditions in the equipment during observation. The multicellular glandular trichomes obviously possess a secretory function and may serve as reservoirs for chemical warfare against terrestrial and airborne predators. A small droplet of exudate was observed in the each pin head of the glandular trichomes on plants observed in the wild. Presence of glandular sessile trichomes restricted to the underside of the leaf suggests an antiherbivory role targeted specifically towards small soil surface foragers, leaf eating insects and worms.

This micro-morphological feature could serve as a taxonomic biomarker for this species. Further, while investigating the stomatal ontogeny in a few Gamopetalae, Devvrat (2016) reported that in Acanthaceae members such as $A$. echioides, "bridges of protoplasmic strands interconnect protoplast of hair cells, epidermal cells and stomatal apparatus." This connectedness of various cell types in the epidermal diaspora implies a physiological relationship that goes beyond just protection or reduced transpiration and possibly suggests the role of foliar absorption by the stomata and trichomes (Franke, 1961). In A. paniculata, sessile glandular trichomes warty multicellular trichomes, sessile multicellular glandular head trichomes, simple multicellular trichomes candelabra trichome with head filled with oil globules and brown pigment were reported Switu (2013). In $A$. serpyllifolia, different trichomes observed are colourless to white indicating absence of any kind of pigmentation including Chlorophyll. Thus trichomes are not part of the photosynthetic activity. Maleic and Giuliani (2006) while reviewing the trichomes of Labiatae described the peltate trichomes as sites of essential oil/terpenes production and accumulation, while the long-stalked capitate trichomes generate and store essential oils and polysaccharides. The phytochemical profiling of trichomes in $A$. serpyllifolia is part of another study undertaken by the authors and is not included in the scope of this study.

\section{Pollen ornamentation}

Bremekamp (1948) suggested that Andrographideae be given a separate tribe status among Acanthoideae. The reticulate ornamentation (a net like appearance) consisting of depressed elements termed as murus separated from each other by a raised border or lumen is fairly common among the family Acanthaceae (Moore et al., 1991). The size of the pollen ranges from $55-60 \mu \mathrm{m}$ along the polar axis and about
60-65 $\mu \mathrm{m}$ along the equatorial axis. The small size of the pollen suggests a wind pollinated species as air borne pollen grains normally range from $10 \mu \mathrm{m}$ to $80 \mu \mathrm{m}$. The bearded anther possibly serves as a trap for drifting pollen, enabling the closely situated stigma to access them with ease. Sporopollenin, a highly stable, tough, plant substance and composite of pollen exine is highly cross-linked polymer composed of carbon, hydrogen, and oxygen (HeslopHarrison, 1971). It has been referred to as the "diamond of the plant world" (Kesseler, 2004), as "probably one of the most extraordinary resistant materials known in the organic world" (Feagri and Iverson, 1964). It is also believed to be composed of long chain fatty acids, phenylpropanoids, phenolics and traces of carotenoids. Considering the relative abundance of pollen production in each flower, and the numerous flowers borne by each plant, the contribution of pollen to the overall bioactives profile of the plant may be significant.

\section{Seed testa}

The deeply reticulate and highly pitted seed surface is unique among the investigated taxa of Andrographideae. In $A$. paniculata, the seed surface or spermoderm has been described as warty with numerous tubercular dome-shaped outgrowths intermingled with undulations. The testa of $A$. serpyllifolia is distinctive with its convolutions which resemble the contusions of the human brain. The anticlinal walls are depressed; therefore furrows are formed between the cells. The periclinal walls are convex and secondary sculpture is of the rugose type. The hard yellow seed coat with waxy fibrils criss crossing its elaborately convoluted polygonal ridges and furrow may render the seed highly impervious to water or moisture. Working on protein induced seed dormancy in $A$. paniculata, Daryush Talei et al. (2012) demonstrated that presence of hard seed coat and high molecular weight proteins prevented germination. Protein profiling with sodium dodecyl sulfate polyacrylamide gel electrophoresis (SDS-PAGE) revealed three polymorphic bands corresponding to specific protein sized $75 \mathrm{kDa}$ in the seed coat and two proteins sized $31 \mathrm{kDa}$ and $69 \mathrm{kDa}$ in endosperm that caused the physiological dormancy. A similar condition may prevail in the seeds of A. serpyllifolia which did not germinate very easily. It is possible that in case of this geophyte of the arid zone, midsummer forest fires may denature the high molecular weight proteins of the testa and melt the fibrillar waxy coating, rendering the seed coat water-permeable. Subsequently, the following monsoon, the water absorption is easier. But, earlier it was mentioned that leaf waxes are not visible in SEM microphotographs. Given that observation, it is worthwhile investigating the nature and composition of these waxy fibrils in the seeds which are revealed in great clarity, depth and appear unaffected by the temperatures subjected to in the SEM chamber. The centrally located microscopic pore in the depression of each polygonal furrow may serve as a gateway for water absorption.

Thus it appears that plant morphology is a function of the prevalent geo-ecological influences and the functional responses determine the phytochemical pathways and hence phytochemical accumulation. The correlation between plant morphology, its functional implications and potential bioactive accumulation has been summarised in Table 2 . 
Table 1. Types of trichomes found in A. serpyllifolia and their distribution on the plant body

\begin{tabular}{|c|c|c|c|}
\hline Plant Parts & $\begin{array}{l}\text { Multicellular simple } \\
\text { trichomes }\end{array}$ & $\begin{array}{l}\text { Stalked glandular } \\
\text { trichomes }\end{array}$ & $\begin{array}{l}\text { Sessile glandular } \\
\text { trichomes }\end{array}$ \\
\hline \multicolumn{4}{|c|}{ Vegetative morphology } \\
\hline \multicolumn{4}{|l|}{ Leaf } \\
\hline Leaf margins & +++ & - & - \\
\hline Abaxial surface & ++ & ++ & - \\
\hline Adaxial surface & - & - & ++++ \\
\hline Petiole & ++ & + & - \\
\hline Stem & +++ & ++ & - \\
\hline Internodes & +++ & ++ & - \\
\hline Nodes & +++ & ++ & - \\
\hline Axillary Buds & +++ & +++ & - \\
\hline \multicolumn{4}{|c|}{ Floral morphology } \\
\hline Pedicel & ++ & + & - \\
\hline Calyx (Sepals) & +++ & ++ & - \\
\hline Corolla (Petals) & + & +++ & - \\
\hline Stamen & ++++ & - & - \\
\hline Filament & +++ & - & - \\
\hline Anther surface & - & - & - \\
\hline Ovary & - & - & - \\
\hline Receptacle & - & - & - \\
\hline Style & + & - & - \\
\hline Stigma & - & - & - \\
\hline Fruit & ++ & - & - \\
\hline Peduncle & ++ & - & - \\
\hline Bracts & ++ & - & - \\
\hline Seed & - & - & - \\
\hline
\end{tabular}

Table 2. Correlation between plant morphology and bioactive accumulation in A. serpyllifolia

\begin{tabular}{|c|c|c|c|}
\hline Morphological feature & Description & Functional aspects & Potential Bioactive Accumulation \\
\hline Habit & Stout root stock & $\begin{array}{l}\text { Storage of nutrients and water } \\
\text { Potential energy centres }\end{array}$ & $\begin{array}{l}\text { Presence of carbohydrates } \\
\text { Presence of starches }\end{array}$ \\
\hline Juvenile shoots & Reddish purple shoots & Preservation of apical shoots & Presence of antioxidants (Flavonoids) \\
\hline High soil temperatures & $\begin{array}{l}\text { Soil surface and aerial } \\
\text { microenvironment }\end{array}$ & $\begin{array}{l}\text { Preservation of internal water } \\
\text { Protection of cellular organelles } \\
\text { from heat }\end{array}$ & Presence of waxes, cuticle \\
\hline Temperature, Water stress & Succulent leaves reduced in size & $\begin{array}{l}\text { Chloroplast protection (Anti- } \\
\text { oxidant activity) }\end{array}$ & Dihydroxy B-ring-substituted flavonoids \\
\hline Stomata & Diacytic & Higher exchange of $\mathrm{CO} 2$ & $\begin{array}{l}\text { Increased primary metabolism; } \\
\text { Photosynthesis } \\
\text { Multiple glycolysis cycles, higher } \\
\text { production of carbohydrates }\end{array}$ \\
\hline \multirow{4}{*}{ Trichomes } & $\begin{array}{c}\text { Presence of short white streak-like } \\
\text { deposits }\end{array}$ & $\begin{array}{l}\text { Preservation of internal water, } \\
\text { light reflectance }\end{array}$ & $\begin{array}{l}\text { Could be biomineral deposits such as } \\
\text { calcium or silica salts }\end{array}$ \\
\hline & $\begin{array}{l}\text { Relative abundance of unicellular } \\
\text { long trichomes }\end{array}$ & $\begin{array}{c}\text { Protection of cellular organelles } \\
\text { from heat }\end{array}$ & Physical barrier for UV penetration \\
\hline & $\begin{array}{c}\text { Relative abundance of sessile } \\
\text { trichomes on the abaxial laminar } \\
\text { surfaces }\end{array}$ & $\begin{array}{l}\text { Chloroplast protection (Anti- } \\
\text { oxidant activity) Protection from } \\
\text { small pests on soil surface }\end{array}$ & Presence of flavonoids, unsaturated lipids \\
\hline & Presence of glandular trichomes & Secretory function & $\begin{array}{l}\text { Presence of terpenoids, low molecular } \\
\text { weight volatiles, polysaccharides }\end{array}$ \\
\hline Pollen & $\begin{array}{l}\text { Yellow, round pollen with } \\
\text { reticulate ornamentation }\end{array}$ & $\begin{array}{l}\text { Protection of microspore from } \\
\text { desiccation or inundation, UV } \\
\text { radiation, heat }\end{array}$ & $\begin{array}{l}\text { Sporopollenin comprised of long } \\
\text { chain fatty acids, phenylpropanoids, } \\
\text { phenolics and traces of carotenoids. }\end{array}$ \\
\hline Testa & Yellow, Rugose with waxy fibrils & $\begin{array}{l}\text { Protection of Embryo from } \\
\text { desiccation or inundation, UV } \\
\text { radiation, heat }\end{array}$ & $\begin{array}{l}\text { High molecular weight proteins, lipids, } \\
\text { waxes }\end{array}$ \\
\hline
\end{tabular}




\section{Conclusions}

Plant morphology directly influences water efficiency, evapotranspiration and gaseous exchange which influence primary metabolism. High primary metabolic potential results in accumulation of a huge substrate-base available for various secondary metabolic pathways to get triggered, creating a vast reservoir of bioactives. While this micromorphology-based phytochemical evaluation has been conducted using $A$. serpyllifolia in the context of this research, such a study may be applicable in any plant species irrespective of its ethnobotanical antecedents. It assists in quick preliminary reverse pharmacognostical, qualitative assessment of phytochemicals in Bioprospecting and herbal drug discovery with minimal expense. The path forward is to substantiate the observations and deductions recorded in this study with targeted, bioactive-specific phytochemical analysis.

\section{Acknowledgements}

We are grateful to the chairman and the team in charge of SEM at SSCU Indian Institute of Science, Bangalore for valuable guidance and permitting use of their facility for this study. We thank Professor Tejawathi for her valuable comments on this paper.

\section{References}

Agati G Azzarello E, Pollastri S, Tattini M (2012). Flavonoids as antioxidants in plants: location and functional significance (Review). Plant Science 196:67-76.

Bremekamp CEB (1948). Notes on the Acanthaceae of Java. Verhandelingen der Koninklijke Nederlandsche Akademie van Wetenschappen, Afdeeling Natuurkunde. Tweede Sectie 45:1-78.

Champion HG, Seth SK (1968). The revised forest types of India. Government of India, New Delhi.

Devvrat C (2016). Structure and development of stomata in some gamopetalae http://hdl.handle.net/10603/76141.

Dharmadasa RM,Samarasinghe K, Adhihetty P, Hettiarachchi PL (2013). Comparative pharmacognostic evaluation of Munronia Pinnata (Wall.) Theob. (Meliaceae) and it's substitute Andrographispaniculata (Burm.F.) Wall. Ex Nees (Acanthaceae). World Journal of Agricultural Research 15:77-81.

Faegri K, Iversen J (1964). Textbook of Pollen Analysis. $2^{\text {nd }}$ Edition, Blackwell, Oxford, pp 237.

Franke W (1961). Ectodesmata and foliar absorption. American Journal of Botany 48:683-691.

Giuliani C, Pellegrino R, Tirillini B, MaleciBini L ( 2008). Micromorphological and chemical characterization of Stachys recta L. subsp. serpentini (Fiori) Arrigoni in comparison to Stachys recta L. subsp. recta (Lamiaceae). Flora 203:376-385.

Grant B, Vatnick I (2004). Teaching issues and experiments in ecology, TIEE volume 1 The Ecological Society of America. (www.tiee.ecoed.net).
Heslop-Harrison J (1971). Sporopollenin in the biological context. In: Brooks J (Ed). Sporopollenin, London \& New York Academic Press: London pp 1-30.

Hickey M, King C (2001). The Cambridge Illustrated glossary of Botanical Terms, Cambridge University Press, ISBN 0-521-790808.

Houghton RA (2005). Aboveground forest biomass and the global carbon balance. Global Change Biology 11:945-958.

Kessler R, Harley M (2004). Pollen. The hidden sexuality of flowers London: Papadakis, pp 264.

Manjunath (2003). Flora of Davangere District. Regency Publications/Daya Publishing House.

Mathew KM (1991). An excursion flora of central Tamil Nadu. New Delhi Oxford \& IBH Publishing Co.

Missouri Botanical Gardens: Http://Swbiodiversity. Og/Seinet/ Taxa/Index.Php?Taxon-Andrographis

Moore PD, Webb JA, Collison ME (1991). Pollen analysis. $2^{\text {nd }}$ Edition, Blackwell Scientific, Oxford.

Neinhuis C, Edelmann HG (1996). Methanol as a rapid fixative for the investigation of plant surfaces by SEM. Journal of Microscopy 184(1):14-16.

Pandey D. (2014), Antimicrobial activity and phytochemical analysis of Urginea indica from Bastar District of Chhattisgarh. International Journal of Pharmaceutical Sciences Review and Research 26(2) 47:273-281

Parixit B, Bharath C, Rajarajeshwari N, Ganapaty S (2012). The Genus Andrographis - A review. International Journal of Pharmaceutical Sciences 4:1835-1856.

Pathan A K, Bond J, Gaskin RE (2009). Sample preparation for SEM of plant surfaces Materials Today 12:32-43.

Raunkier C (1937). Life-form, genus area, and number of species. Botaniske Studier.

Saldanha S, Nicolson D (1976). Flora of Hassan District. New Delhi : Published for the Smithsonian Institution and the National Science Foundation by Amerind Pub. Co.

Schweitzer J (2014). Scanning Electron Microscope Https:// www.purdue.edu/ehps/rem/rs/sem.htm

Switu J, Harisha CR, Patel BR (2013). Variations of trichomes in family Acanthaceae W.S.R to Kalmegh - a micromorphological and micrometric study. International Journal of Universal Pharmacy and Bio Sciences 2(6):526-533.

Talei D, Kadir MA, Yusop MK, Valdiani A, Abdullah MP (2012). Physico-protein based dormancy in medicinal plant of Andrographis paniculata. Journal of Medicinal Plants Research 6(11):2170-2177.

Thakur HA, Patil DA (2014). Foliar Epidermal Studies of Plants in Euphorbiaceae Taiwania 59(1):59-70.

Weigend M, Ackermann M (2015). Loasaceae. In: Jörgensen PM (Ed). Checklist of the Flora of Bolivia. Missouri Botanical Gardens Monographs No. X: 763-765. 